\title{
TINF2 wt Allele
}

National Cancer Institute

\section{Source}

National Cancer Institute. TINF2 wt Allele. NCI Thesaurus. Code C51007.

Human TINF2 wild-type allele is located within $14 q 12$ and is approximately $3 \mathrm{~kb}$ in length.

This allele, which encodes TERF1-interacting nuclear factor 2 protein, plays a role in the regulation of telomere length and elongation. 